\title{
Pembinaaan Toleransi Antar Umat Beragama Perspektif Pendidikan Agama Islam Bagi Remaja Kota Kendari
}

\author{
Herman; Mohamad Rijal \\ Fakultas Tarbiyah dan Ilmu Keguruan Institut Agama Islam Negeri Kendari \\ Corresponding Author: mohamadrija102@gmail.com
}

\begin{abstract}
This research is an effort to reveal the portrait of religious tolerance among religious perspectives of Islamic religious education perspective for adolescents in Kendari Barat of Kendari. The main questions addressed in this study are (1) how to foster interfaith religious tolerance among youths in Kendari? and (2) How Islamic education is perceived by teenagers in Kendari. To address the questions, the researcher employs several research methods. The method used in data analysis is descriptive method in which the authors provide descriptive on the subject of researchers based on variable data obtained from the group of subjects studied. The findings of this study indicate that, (1) in fostering the attitude of tolerance among adherents for adolescents in of Kendari, among others, fostering adolescents not to question differences of beliefs to other religions, fostering adolescents not to disturb other followers when running religious services, fostering adolescents not to force adherents of other faiths to convert to Islam and foster adolescents in order not to force followers of other faiths to follow religious activities. While (2) Islamic education for teenagers by parents in Kendari, among others, adolescents always appreciate the elderly even though he has different religion, be gentle in family life and community, help others in need though the person is another religion, guide teenagers so as not to criticize other faiths and always build relationships with followers of other religions.
\end{abstract}

\section{Keywords: Islamic Religious Education; tolerance; youth}

\begin{abstract}
Abstrak
Penelitian ini mengkaji pembinaan toleransi antar umat beragama perspektif pendidikan agama Islam bagi remaja di Kecamatan Kendari. Hasil penelitian menunjukkan bahwa pembinaan sikap toleransi antar umat beragama bagi remaja dilakukan dengan tujuan agar remaja tidak mempersoalkan perbedaan keyakinan kepada pemeluk agama lain, tidak mengganggu pemeluk lain ketika menjalankan ibadah, tidak memaksa pemeluk agama lain untuk masuk Islam serta tidak memaksa pemeluk agama lain untuk mengikuti kegiatan-kegiatan keagamaan agama lain. Penelitian ini juga menemukan bahwa para remaja di Kendari senantiasa menghargai orang yang lebih tua walaupun dia beragama lain, bersikap lemah lembut dalam kehidupan keluarga dan bermasyarakat, membantu sesama yang membutuhkan walaupun beragama lain, membimbing remaja agar tidak mencela pemeluk agama lain serta senantiasa membina hubungan silaturahmi dengan pemeluk agama lain.
\end{abstract}

Kata kunci: pendidikan agama Islam; remaja; toleransi

\section{A. Pendahuluan}

Era sekarang adalah era multikultural dan plural, dimana seluruh masyarakat dengan segala unsurnya dituntut untuk saling tergantung dan menanggung nasib secara bersama-sama demi terciptanya perdamaian abadi. Salah satu bagian penting dari konsekuensi tata kehidupan global yang ditandai kemajemukan etnis, budaya, dan agama tersebut, adalah membangun dan menumbuhkan kembali teologi pluralisme dalam masyarakat.

Tingginya pluralisme bangsa Indonesia membuat potensi konflik bangsa Indonesia juga tinggi. Potensi perpecahan dan kesalahpahaman juga tinggi, baik konflik dalam skala kecil 
maupun besar. ${ }^{1}$ Dalam skala kecil, konflik tercermin pada komunikasi yang tidak tersambung atau tidak berjalan sebagaimana mestinya, sehingga menyebabkan rasa tersinggung, marah, frustasi, kecewa, dongkol, bingung, bertanya-tanya, sementara itu konflik dalam skala besar mewujud dalam, misalnya kerusuhan sosial, kekacauan multi budaya, perseturuan antar ras, etnis, dan agama.

Pluralisme merupakan sebuah realitas sosial yang siapapun tidak mungkin mengingkarinya, karena pluralisme juga merupakan hukum Allah (sunatullah). Pluralisme harus disertai dengan kesadaran teologi bahwa kehidupan, terutama kehidupan agama ini memang plural dan itu merupakan kehendak Allah. ${ }^{2}$

Demi terwujudnya sikap toleransi, maka pendidikan pluralisme dianggap sebagai instrumen penting. Sebab pendidikan sampai sekarang masih mempunyai peran besar dalam membentuk karakter individu-individu yang didiknya, dan mampu menjadi "guiding light" bagi generasi muda penerus bangsa. Dalam konteks inilah, pendidikan agama sebagai media penyadaran umat perlu membangun teologi inklusif dan pluralis, demi harmonisasi agama-agama, khususnya remaja di Kota Kendari. Menurut PBB, usia remaja (youth) adalah rentang usia 15-24 tahun. Sementara kategori remaja menurut Menteri Kesehatan RI tahun 2010, adalah antara 10 sampai 19 tahun dan belum kawin. Secara lebih spesifik, Nilan dan Feixa memberikan definisi remaja merujuk pada rentang antara 12 hingga 35 tahun. ${ }^{3}$ Masa remaja diidentikan sebagai masa-masa transisi dan penuh gejolak, baik biologis, psikologis, sosial mupun ekonomis. Masa remaja juga disebut masa yang penuh dengan gejolak dan kegoncangan. Periode ini merupakan periode teransisi atau peralihan dari kehidupan masa kanak-kanak ke masa dewasa ${ }^{4}$. Oleh sebab itu masa ini termasuk usia yang rentan sekaligus juga mudah untuk dipengaruhi hal-hal baru, termasuk dalam menyuntikan ide-ide radikalisme, bahkan terorisme. Remaja sebagai sasaran pendidikan pluralisme oleh sebab dalam banyak penelitian para remaja menunjukan kecenderungan ke arah radikal dan banyak para remaja yang terpapar maupun ikut aktif dalam upaya-upaya radikalisme. ${ }^{5}$ Banyak pula penelitian lain yang menunjukan bagaimana kaum muda menjadi kategori sosial yang rentan dan mudah jatuh dalam paham-paham radikalisme. Sebagaimana yang ditemukan oleh Ahmad Gaus AF ${ }^{6}$; M. Zaki Mubarak ${ }^{7}$; Laporan invesitigas Tempo ${ }^{8}$.

Pencegahan paham-paham radikalisme dikalangan remaja dapat dilakukan dengan berbagai cara, salah satunya adalah lewat pendidikan agama Islam. Pendidikan agama Islam yang dimaksudkan disini adalah meluruskan kembali pemahaman para siswa tentang tasir-tafsir agama yang selama ini dibelokan ke arah paham-paham radikal. Hal tersebut sebagaimana dijelaskan oleh Abdul Rahman Saleh bahwa "Salah satu tujuan pendidikan agama yaitu pendidikan agama harus mampu mewujudkan keharmonisan, kerukunan, dan rasa hormat internal agama yang

1 Ahmad Syahid, Riuh di Beranda Satu:Peta Kerukunan Umat Beragama di Indonesia, (Jakarta: Departemen Agama RI bekerjasama dengan Badan Litbang Agama dan Diklat Keagamaan serta Puslitbang Kehidupan Beragama, 2003), h.1

${ }^{2}$ Rahmat Imadadun, Islam Pribumi Mendialogkan Agama, Membaca Realita,(Jakarta: Erlangga, 2003) h. 186.

${ }^{3}$ Pam Nilan dan Charles Feixa, Global Youth? Hybrid Identity, Plural Worlds, (New York: Routledge, 2006).

${ }^{4}$ Dadang Sulaiman, Psikolog Remaja Dimensi-Dimensi Remaja Perkembangan, (Bandung: CV. Mandar Maju, 1995), h. 1.

${ }^{5}$ Hasil penelitian Maarif Institute pada Desember 2015 dimuat dalam Harian Umum Kompas Nasional. 02 maret 2016; Hasil survei The Pew Research Center tahun 2015; Penelitian Ahnaf (2012).

${ }^{6}$ Ahmad Gaus AF, "Pemetaan Problem Radikalisme di SMU Negeri di 4 Daerah", Jurnal Ma'arif, Vol. 8 No. 1 (Juli 2013): 174-191.

7 M. Zaki Mubarak, "Dari Semangat Islam Menuju Sikap Radikal: Pemikiran dan Perilaku Keberagamaan Mahasiswa UIN Syarif Hidayatullah Jakarta”, Jurnal Ma'arif, Vol. 8 No. 1 (Juli 2013): 192-217.

${ }^{8}$ Majalah Tempo, "Investigas Paham Radikal di kampus Kita”, 28 Mei-3 Juni 2018. 
dianut dan terhadap pemeluk agama lain". 9 Pendidikan agama adalah sebagai wahana untuk mengeksplorasi sifat dasar keyakinan agama di dalam proses pendidikan dan secara khusus mempertanyakan adanya bagian dari pendidikan keimanan kepada remaja. Dengan pemahaman agama Islam yang sebenarnya, akan mampu merefleksikan persoalan pluralitas, dengan mentransmisikan nilai-nilai yang dapat menumbuhkan sikap toleran, terbuka dan kebebasan dalam diri generasi muda atau remaja. Melalui pengembangan pendidikan agama Islam berbasis kemajemukan akan dapat dijadikan sebagai jawaban atau solusi alternatif bagi keinginan untuk merespon persoalan-persoalan di atas. Sebab dalam pendidikan ini, pemahaman Islam yang hendak dikembangkan oleh pendidikan berbasis plural adalah pemahaman dan pemikiran yang bersifat inklusif.

Banyak penelitian yang telah dilakukan terkait dengan penanaman nilai-nilai toleransi dengan perspektif pendidikan agama Islam, sebagaimana yang dilakukan oleh Anis Farikhatin tentang bagaimana membangun keberagamaan Inklusif-Dialogis di SMA PIRI I Yogyakarta ${ }^{10}$; Retno Listyarti melakukan penelitian tentang bagaimana menanamkan pendidikan multikultural dan anti kekerasan melalui Permainan Garis ${ }^{11}$; penelitian Ali Maksum tentang Model Pendidikan Toleransi di pesantren modern Gontor Ponorogo dan pesantren salaf Tebuireng Jombang ${ }^{12}$. Penelitian-penelitian tersebut sama-sama menyasar remaja atau pemuda sebagai sasaran pendidikan agama Islam untuk menumbuhkan nilai-nilai toleransi. Penelitian ini difokuskan pada kaum remaja di Kota Kendari yang dianggap sebagai lokasi perkotaan. Penelitian ini juga diarahkan pada bagaimana memberikan orientasi untuk memberikan penyadaran terhadap para remaja akan pentingnya saling menghargai, menghormati dan bekerja sama dengan agama lain.

Kota Kendari merupakan sebuah daerah yang memiliki latar belakang agama yang berbeda-beda. Selain itu, kota Kendari pada masa-masa sekarang menjadi ladang subur bagi tumbuh suburnya lembaga-lembaga pendidikan Islam bernuansa radikal dalam bentuk sekolahsekolah formal. Salah satu diantaranya adalah hadirnya Islamic Centre Mu'adz bn Jabal di kota Kendari yang diminati oleh jama'ah menengah keatas. ${ }^{13}$ Masyarakat kota sebagai kategori masyarakat modern perkotaan mengalami kecenderungan kea rah intoleran, sebagaimana data yang diungkapkan oleh Pusat Pengkajian Islam dan Masyarakat (PPIM) UIN Syarif Hidayatullah tahun 2018 menunjukkan bahwa 63,07\% guru memiliki opini intoleran pada pemeluk agama lain, sementara yang memiliki opini toleransi terhadap pemeluk agama lain sebanyak $36,92 \%{ }^{14}$. Hal ini menunjukan bahwa masyarakat kota yang paling banyak dipengaruhi kehidupan modern dan globalisasi nyatanya adalah masyarakat yang juga terpapar paham-paham radikal.

\section{B. Konsep Sikap Toleransi Antar Umat Beragama}

\footnotetext{
${ }^{9}$ Abdul Rahman Saleh, Pendidikan Agama dan Pembangunan Watak Bangsa, (Jakarta: PT. Raja Grafindo Persada, 2006), h. 2.

${ }^{10}$ Anis Farikhatin, "Membangun Keberagamaan Inklusif-Dialogis di SMA PIRI I Yogyakarta", Jurnal Ma'arif, Vol. 8 No. 1 (Juli 2013): 109-131.

${ }^{11}$ Retno Listyarti, "Pendidikan Multikultural dan Anti Kekerasan Melalui Permainan Garis", Jurnal Ma'arif, Vol. 8 No. 1 (Juli 2013): 97-108.

${ }^{12}$ Ali Maksum, "Model Pendidikan Toleransi Di Pesantren Modern Dan Salaf", Jurnal Pendidikan Agama Islam Vol. 03, No. 01, (Mei 2015): 82-108.

${ }^{13}$ Asliah Zainal, "Pola Pendidikan Dan Pola Dakwah Islamic Centre Mu'adz Bin Jabal (ICM) Di Kota Kendari”, Jurnal Al Izzah, Vol. Vol 12, No.2, Nov 2017: 44-66. http://ejournal.iainkendari.ac.id/alizzah/article/view/640/594. Diakses tanggal 5 Februari 2018.

${ }^{14}$ Hasil Survey PPIM UIN Syarid Hidayatullah Jakarta 2018, "Pelita yang Meredup: Potret Keberagamaan Guru Indonesia”. Jakarta: Pusat Pengkajian Islam dan Masyarakat (PPIM) UIN Syarif Hidayatullah, 2018.
} 
Indonesia adalah negara yang plural, namun pluralisme agama bukanlah kenyataan yang mengharuskan orang untuk saling menjatuhkan, saling merendahkan atau membandingbandingkan antara agama satu dengan yang lain. Menempatkan posisi yang saling menghormati, saling mengakui dan kerjasama itulah yang harus dilakukan semua pemeluk agama. Sikap yang harus dimiliki oleh setiap umat dalam menempatkan berbagai perbedaan, yaitu hidup menghormati, memahami dan mengakui diri sendiri, tidak ada paksaan, tidak mementingkan diri sendiri maupun kelompok. ${ }^{15}$

Dengan menerapkan sikap toleransi bertujuan untuk mewujudkan sebuah persatuan diantara sesama manusia dan warga negara Indonesia khususnya, tanpa mempermasalahkan latar belakang agamanya. Seluruh agama yang di muka bumi mengajarkan tentang kebaikan, tidak ada yang mengajarkan untuk berbuat kerusakan atau kejahatan. Demikian juga dengan hidup rukun damai, hidup berdampingan dengan agama lain, atau dikenal dengan sikap toleransi. Di dalam memaknai toleransi terdapat dua penafsiran. Pertama, penafsiran yang bersifat negatif yang menyatakan bahwa toleransi itu cukup mensyaratkan adanya sikap membiarkan dan tidak menyakiti orang atau kelompok lain baik yang berbeda maupun yang sama. Sedangkan yang kedua adalah yang bersifat positif yaitu menyatakan bahwa harus adanya bantuan dan dukungan terhadap keberadaan orang lain atau kelompok lain. ${ }^{16}$

Toleransi dalam pelaksanaanya dalam sikap harus didasari pula oleh sikap kelapangan dada terhadap orang lain dengan tetap memperhatikan prinsip-prinsip yang dipegang sendiri, yakni tanpa mengorbankan prinsip-prinsip tersebut. ${ }^{17}$ Rasa penuh keikhlasan dan dapat menerima hal-hal yang tidak sama dengan prinsip yang dipegang sendiri tetapi hal tersebut tak lantas membuat dasar prinsip sendiri hilang bahkan membuatnya semakin kuat.

Toleransi beragama mempunyai arti sikap lapang dada seseorang untuk menghormati dan membiarkan pemeluk agama untuk melaksanakan ibadah mereka menurut ajaran dan ketentuan agama masing-masing yang diyakini tanpa ada yang mengganggu atau memaksakan baik dari orang lain maupun dari keluarganya sekalipun. ${ }^{18}$ Karena manusia memiliki hak penuh dalam memilih, memeluk dan meyakini sesuai dengan hati nuraninya. Tak seorang pun bisa memaksakan kehendaknya. Untuk itu toleransi beragama sangatlah penting untuk menciptakan kerukunan umat beragama. Sedangkan dalam agama Islam yang menjadi landasan toleransi beragama terdapat dalam Q.S. Al-Qafirun 109:1-6 yaitu:

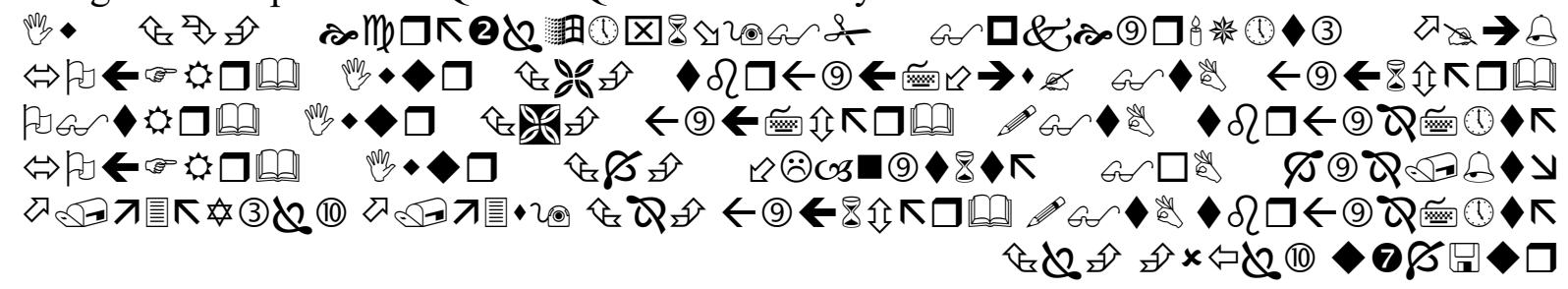

\section{Terjemahannya:}

"Katakanlah" Hai orang-orang kafir, Aku tidak akan menyembah apa yang kamu sembah, Dan kamu bukan penyembah Tuhan yang aku sembah. Dan aku tidak pernah menjadi penyembah apa yang kamu sembah, dan kamu tidak pernah menjadi penyembah Tuhan yang aku sembah. Untukmu agamamu, dan untukkulah, agamaku". ${ }^{19}$

\footnotetext{
${ }^{15}$ Elga Sarapung, Pluralisme, Konflik dan Perdamaian, (Yogyakarta: Pustaka Pelajar, 2002), h. 8.

${ }^{16}$ Masykuri Abdullah, Pluralisme Agama dan Kerukunan dalam Keragaman, (Jakarta: Penerbit Buku Kompas, 2001), h. 13.

${ }^{17}$ H. M Ali dkk, Islam untuk Disiplin Ilmu Hukum Sosial dan Politik, (Jakarta: Bulan Bintang, 1989), h. 80 .

${ }^{18}$ H. M Ali dkk, Islam untuk Disiplin Ilmu Hukum Sosial dan Politik....., h. 83

${ }^{19}$ Departemen Agama RI, Hubungan Antar Umat Beragama (Tafsir Al-quran Tematik), (Jakarta: Departemen Agama,2008), h 83-86.
} 
Dikandungan surat Al-Kafirun itu para ahli telah mencoba menarik beberapa garis hukum diantaranya adalah (1) tidak seorangpun boleh dipaksa untuk memeluk agama lain atau meninggalkan ajaranya agamnya dan (2) setiap orang berhak untuk beribadat menurut ketentuan ajaran agamanya masing-masing. Maka berdasarkan ayat tersebut jelaslah bahwa agama tidak pernah berhenti dalam mengatur tata kehidupan manusia. Di dalam kehidupan masyarakat Indonesia dikembangkan sikap hormat-menghormati dan bekerja sama antara pemeluk agama dan antara penganut kepercayaan yang berbeda sehingga toleransi beragama dapat diterapkan dan kerukunan umat beragama dapat terwujud dengan baik.

Umat beragama pada saat ini menghadapi problematika baru bahwa konflik agama sebagai fenomena nyata. Karena hal tersebut umat beragama harus menemukan titik persamaan, bukan mencari perbedaan yang pada akhirnya jatuh pada konflik sosial. Namun pada kenyataanya, sejarah sudah membuktikan bahwa konflik agama menjadi sangat rentan, bahkan sampai menyulut pada rasa dendam oleh umat-umat sesudahnya. Inti masalah sesungguhnya bahwa perselisihan atau konflik antar agama adalah terletak pada ketidakpercayaan dan adanya saling curiga. Masyarakat agama saling menuduh satu sama lain sebagai yang tidak toleran, dan keduanya menghadapi tantangan konsep-konsep toleransi agama. Tanpa harus mempunyai kemauan untuk saling mendengarkan satu sama lain. Inilah sah satu satu sebab terjadinya ketidakharmonisan umat beragama di Indonesia.

Inilah mengapa memiliki rasa saling toleransi antar umat beragama sangat diperlukan. Karena toleransi beragama memiliki tujuan dan fungsi yang tak hanya untuk keberlangsungan masyarakat dalam jangka waktu sesaat, tetapi kemaslahatanya akan dirasakan dalam waktu yang panjang. Dalam kehidupan bermasyarakat rukun dan damai akan terwujud bila masyarakat menerapkan sikap toleransi. Dengan menerapkan sikap toleransi, kehidupan bermasyarakat akan menjadi lebih tentram dan damai, hal ini akan menumbuhkan suasana yang kondusif sehingga dapat menghilangkan kecemasan dan ketakutan akan adanya tindakan negatif dari agama lain. Masyarakat akan memandang perbedaan agama dengan kaca mata positif dan tidak menjadikan perbedaan agama sebagai suatu masalah besar dan berakibat fatal.

Kerukunan hidup beragama merupakan salah satu tujuan toleransi beragama. Hal ini dilatar belakangi beberapa kejadian yang memperlihatkan gejala meruncingnya hubungan antar agama. Kehadiran agama-agama besar mempengaruhi perkembangan kehidupan bangsa Indonesia dan menambah corak kemajemukan bangsa Indonesia, walaupun kemajemukan itu mengandung potensi konflik, namun sikap toleransi diantara pemeluk berbagai agama besar benar-benar merupakan suatu kenyataan dalam kehidupan bangsa Indonesia. ${ }^{20}$

\section{Hakikat Pendidikan Agama Islam}

Pendidikan Agama Islam adalah pendidikan dengan melalui ajaran agama Islam yaitu, berupa bimbingan dan asuhan terhadap anak didik agar setelah selesai dari pendidikan ia dapat memahami, menghayati dan mengamalkan ajaran-ajaran agama Islam yang diyakininya secara menyeluruh, serta menjadikan acara Islam itu sebagai suatu pandangan hidupnya demi keselamatan dan kesejahteraan hidup di dunia maupun akhirat kelak. Pendidikan Islam adalah usaha sadar orang dewasa yang bertaqwa secara sadar dan membimbing pertumbuhan serta perkembangan fitrah (kemampuan dasar) siswa melalui ajaran Islam ke arah titik maksimal pertumbuhan dan perkembangannya. ${ }^{21}$ Ahmad D Marimba dan Ahmad Tafsir mengemukakan bahwa:

${ }^{20}$ Djohan Effendi, Dialog antar Agama, bisakah melahirkan kerukunan Agama dan Tantangan Zaman, (Jakarta: LP3ES, 1985), h. 169.

${ }^{21}$ H.M. Arifin, Ilmu Pendidikan Islam, (Jakarta: PT. Bumi Aksara, 2014), h. 22. 
Pendidikan Islam adalah bimbingan yang diberikan seseorang agar ia berkembang secara maksimal sesuai ajaran Islam ${ }^{22}$. Mencermati dari pendapat di atas dapat dipahami Pendidikan Agama Islam diartikan sebagai usaha mengubah tingkah laku individu dalam kehidupan pribadinya atau kehidupan dalam alam sekitarnya melalui proses pendidikan agama tersebut, sehubungan dengan hal tersebut sebagai acuan selanjutnya dikemukakan bahwa: Pendidikan Islam adalah bimbingan atau pimpinan secara sadar aleh pendidikterhadap perkembangan jasmani dan rohani siswa menuju terbentuknya kepribadian yang utama (Insan Kamil) ${ }^{23}$.

Dari uraian di atas, maka dapat dipahami bahwa Pendidikan Agama Islam merupakan upaya atau usaha dalam membina dan mengembangkan potensi-potensi yang ada dalam diri pribadi-pribadi manusia yang diupayakan seoptimal mungkin sehingga individu mengalami perkembangan kearah yang diinginkan dalam mencapai kepribadian muslim yang harmonis jasmaniah dan rohaniyah sesuai dengan ajaran Islam menuju kepada kebahagian hidup di dunia dan akhirat. Pendidikan Agama Islam adalah usaha sadar yang terencana dalam menyiapkan siswa untuk mengenal, memahami, menghayati hingga mengimani, bertakwa, dan berakhlak muliadalam mengamalkan ajaran Islam dari sumbernya al-Qur'an dan al-Hadits melalui kegiatan bimbingan. Syed Sajjad Husain dan Syed Ali Asyraf sebagaimana yang dikutip Khoiron Rosyadi, mengartikan bahwa:

Pendidikan Islam adalah suatu pendidikan yang melatih perasaan siswa sedemikian rupa, sehingga dalam sikap hidup, tindakan, keputusan dan pendekatan mereka terhadap segala jenis pengetahuan mereka dipengaruhi sekali oleh nilai spiritual, dan sangat sadar akan nilai etis Islam $^{24}$

Oleh sebab itu, dapat diasumsikan bahwa Pendidikan Agama Islam berfungsi sebagai pengembangan keimanan dan ketaqwaan kepada Allah SWT, serta mengarahkan siswa untuk berakhlak mulia yang ditanamkan terlebih dahulu dalam lingkungan keluarga, serta menanamkan ajaran Islam sebagai pedoman untuk kebahagiaan dunia dan akhirat.

\section{Pembinaan Sikap Toleransi Antar Umat Beragama Bagi Remaja Di Kota Kendari}

Toleransi dalam beragama bukan berarti kita hari ini boleh bebas menganut agama tertentu dan esok hari kita menganut agama yang lain atau dengan bebasnya mengikuti ibadah dan ritualitas semua agama tanpa adanya peraturan yang mengikat. Akan tetapi, toleransi beragama harus dipahami sebagai bentuk pengakuan kita akan adanya agama-agama lain selain agama kita dengan segala bentuk system, dan tata cara peribadatannya dan memberikan kebebasan untuk menjalankan keyakinan agama masing-masing.

Pembinaan toleransi memang tidak bisa hanya sebatas diceramahkan, tetapi harus dipraktekkan dalam kehidupan sehari-hari peserta didik ditingkat sekolah, keluarga, maupun masyarakat. Pembinaan sikap toleransi antara umat beragama kepada remaja di Kota Kendari diantaranya adalah pembinaan agar tidak mempersoalkan perbedaan keyakinan kepada pemeluk agama lain. Hal ini sesuai dengan pernyataan informan yang menyatakan bahwa; "Karena kalau mereka tidak membimbing maka akan terjadi di desa ini ketidak rukunan antar sesama umat beragama" 25

\footnotetext{
${ }^{22}$ Ahmad Tafsir, Ilmu Pendidikan Dalam Prespektif Islam, (Bandung: Remaja Rosdakarya, 2001), h. 32.

${ }^{23}$ Al-rasyidin dan Syamsul Nizar, Filsafat Pendidikan Islam, (Jakarta: Grafindo Persada, 2005), h. 32.

${ }^{24}$ Khoiron Rosyadi, Pendidikan Profetik, (Cet. 1; Jogyakarta: Pustaka Pelajar, 2004), h. 149.

${ }^{25}$ Rahmat, Lurah Mandonga,“Wawancara”, Mandonga, 4 Juli 2017
} 

bahwa:

Pernyataan tersebut senada dengan pernyataan seorang informan yang menyatakan

Berbagai aktifitas remaja yang ada di sini selalu berada dalam bimbingan dan pengawasan kami. Adapun cara saya membimbing anak adalah dengan cara memberikan contoh yang baik, penasehatan dan pengawasan terhadap hal-hal yang bertentangan dengan agama Islam yaitu dengan tidak mempersoalkan perbedaan keyakinan kepada pemeluk lain ${ }^{26}$

Kedua pernyataan tersebut didukung oleh pernyataan seorang informan yang menyatakan bahwa:

Orang tua saya mengajarkan bahwa kita tidak boleh mempersoalkan perbedaan keyakinan kepada pemeluk agama lain apabila itu terjadi maka ketidak nyamanan antar pemeluk agama akan terjadi ${ }^{27}$

Berdasarkan kedua pernyataan yang penuliskan dapatkan dari informan tersebut di atas, maka dapat dipahami bahwa Pembinaan sikap toleransi antara umat beragama dengan memberikan pembinaan kepada remaja agar tidak mempersoalkan perbedaan keyakinan kepada pemeluk agama lain telah terlaksana.

Bentuk pembinaan kedua terkait sikap toleransi antara umat beragama di Kota Kendari adalah membina remaja agar tidak mengganggu pemeluk agama lain ketika menjalankan ibadah keagamaan. Hal ini sesuai dengan pernyataan informan bahwa:

Ada beberapa kesepakatan yang telah dikeluarkan oleh pemerintah bahwa apa bila seorang yang dengan sengaja mengganggu ketentraman orang menjalankan atau melaksanakan ibadah keagamaan akan di berikan sangsi. Jadi saya selaku kepala desa selalu memberikan arahan kepada remaja dan alhamdulillah sampai sekarang belum ada kejadian saling mengganggu antara pemeluk agama di desa kami tersebut ${ }^{28}$

Pernyataan tersebut senada dengan pernyataan seorang informan bahwa:

Saya sebagai orang tua dalam membina ahlak remaja di disini tersebut selalu memberikan bimbingan perlunya saling menghargai dengan membiarkan atau tidak mengganggu pemeluk agama lain ketika menjalankan ibadah keagamaan ${ }^{29}$

Kedua pernyataan tersebut didukung oleh pernyataan seorang informan bahwa:

Menurut saya arang tua membina karena apa bila menjadi hal seperti demikian maka akan tidak ada keharmonisan antara sesama pemeluk di desa kami ini dan akan menjadi hal-hal yang tidak di inginkan ${ }^{30}$

Berdasarkan ketiga pernyataan tersebut di atas, maka dapat dipahami bahwa pembinaan sikap toleransi antara umat beragama dengan membina remaja agar tidak mengganggu pemeluk lain ketika menjalankan ibadah keagamaan telah terlaksana.

Bentuk ketiga dari pembinaan sikap toleransi antara umat beragama di Kota Kendari adalah membina remaja agar tidak memaksa pemeluk agama lain untuk masuk Islam. Hal ini sesuai dengan pernyataan informan bahwa:

Orang tua selalu memberikan pembinaan karena apabila memaksa itu berarti tidak menghargai pemeluk agama lain yang merupakan kepercayaan mereka ${ }^{31}$

\footnotetext{
${ }^{26}$ Ahmad Taufik, Orang Tua Remaja, “Wawancara”, Mandonga , 6 Juli 2017

${ }^{27}$ Muh. Rizal, Remaja ,"Wawancara”, Mandonga, 7 Juli 2017

${ }^{28}$ Rahmat, Lurah Mandonga,"Wawancara”, Mandonga, 4 Juli 2017

${ }^{29}$ Muis, Orang Tua Remaja, "Wawancara”, Mandonga , 6 Juli 2017

${ }^{30}$ Tito, Remaja ,"Wawancara”, Mandonga , 7 Juli 2017

${ }^{31}$ Lurah Tipulu,“Wawancara Mandonga, 4 Mei 2017
} 
Pernyataan informan tersebut di atas, senada dengan pernyataan seorang informan bahwa pembinaan yang diberikan orang tua kami yaitu kita tidak boleh memaksa sama saja kita mencari kesibukan karena setiap agama tidak akan mau di paksa.

Kami selaku orang tua memberikan bimbingan agar tidak memaksa agama lain untuk mengikuti kegiatan-kegiatan keagamaan kami masyarakat disini menjunjung tinggi kegiatan-kegiatan keagamaan yang dilakukan agama lain karena setiap agama sudah mempunyai kegiatan keagamaan masing-masing dan setiap agama tidak akan mungkin mau di paksa ${ }^{32}$

bahwa:

Kedua pernyataan tersebut di atas, didukung oleh pernyataan seorang informan

Orang tua sering memberikan pembinaan kepada kami terkait dengan moral keagamaan yaitu bagaimana cara yang seharusnya kami lakukan untuk menghormati agama lain dengan cara tidak memaksa pemeluk agama lain untuk masuk agama Islam karena mereka mempunyai agama sendiri. Oleh karena itu kami selaku anak selalu berupaya semaksimal mungkin untuk melaksanakan apa yang menjadi anjuran dan arahan orang tua $\mathrm{kami}^{33}$

Berdasarkan pernyataan tersebut di atas, maka dapat dipahami bahwa dalam membina anak remaja yang dilakukan oleh orang tua yang tinggal di Kota Kendari yakni memberikan pemahaman kepada mereka agar tidak memaksa pemeluk agama lain untuk masuk Islam telah terlaksana.

Bentuk keempat dari pembinaan sikap toleransi antara umat beragama di Kota Kendari adalah membina remaja agar tidak memaksa pemeluk agama lain untuk mengikuti kegiatan-kegiatan keagamaan. Hal ini sesuai dengan pernyataan informan bahwa; "Menurut saya orang tua membina anaknya agar tidak memaksa pemeluk agama lain untuk mengikuti kegiatan keagamaan Islam"34

Pernyataan tersebut senada dengan pernyataan seorang informan bahwa:

Membina agar para remaja tidak memaksakan karena dengan memaksa agama lain pasti akan merasa tersinggung dan tidak terjadi keharmonisan ${ }^{35}$

Kedua pernyataan tersebut didukung oleh pernyataan seorang informan bahwa:

Kita tidak boleh memaksa memeluk agama lain untuk masuk Islam itu berarti kita meremehkan pemeluk agama lain apabila pemeluk agama lain untuk masuk Islam harus dengan keikhlasan hati tanpa ada paksaan dari pihak siapapun ${ }^{36}$

Berdasarkan pernyataan tersebut di atas, maka dapat dipahami bahwa dalam membina Pendidikan Islam bagi anak remaja di Kota Kendari yakni tidak memaksa pemeluk agama lain untuk mengikuti kegiatan-kegiatan keagamaan telah terlaksana.

Data-data tersebut mencerminkan masih dilakukanya pola-pola pembinaan pada para remaja di kota Kendari. Namun demikian, pola-ola pembinaan tersebut masih sangat rentan, sebab masih bersifat himbauan semata. Pola dan bentuk pembinaan ini mesti terus dikuatkan dengan cara-cara yang lebih strategis agar toleransi diantara remaja masih dapat terpelihara dengan baik. Nilai toleransi ini bisa dikuatkan dengan bentuk pembinaan dimana orang tua

\footnotetext{
${ }^{32}$ Musdar, Orang Tua Remaja, “Wawancara”, Mandonga 6 Mei 2017

${ }^{33}$ Ansarullah, Remaja,"Wawancara”, Benu-Benua 7 Mei 2017

${ }^{34}$ Ririn, Lurah, "Wawancara”,Benu-Benua 4 Mei 2017

${ }^{35}$ Darmawanto, Orang Tua Remaja, “Wawancara, Benu-Benua, 6 Mei 2017

${ }^{36}$ Rifai, Remaja ,"Wawancara”, Mandonga, 7 Mei 2017
} 
dan guru menegaskan bagaimana ajaran Islam sarat dengan nilai-nilai toleransi sebagaimana dijelaskan Zuhairi Misrawi. ${ }^{37}$ Hanya saja, toleransi tersebut sering disalahpahami dengan sempit.

Jika mencermati data-data diatas, maka model pembinaan tolerasi pada remaja berjalan dengan cukup baik di Kota Kendari. Membandingkan dengan data di kota lain, misalnya data hasil survey Lembaga Kajian Islam dan Perdamaian (LaKIP) Jakarta pada tahun 2010 yang menyebutkan bahwa sebanyak 48,9\% siswa di Jabodetabek menyatakan persetujuannya terhadap aksi radikal. ${ }^{38}$ Temuan tersebut juga mengisyaratkan betapa pentingnya peran guru, khususnya guru Pendidikan Agama Islam (PAI) dalam menangkal paham-paham radikalisme bagi remaja. Oleh sebab itu, guru PAI dituntut untuk dapat menciptakan iklim keagaman yang dapat menghindari paham radikalisme Islam di sekolahsekolah, salah satu diantaranya adalah praktik pembelajaran deradikalisasi pendidikan Islam melalui pengintegrasian nilai-nilai pendidikan anti terorisme pada pembelajaran $\mathrm{PAI}^{39}$. Saat ini, interpretasi terhadap Islam banyak dibelokan kea rah radikalisme, lewat berbagai macam cara dan media. Radikalisme juga telah masuk ke sekolah-sekolah. Jika hal ini tidak segera diantisipasi, maka dapat membantu dalam menumbuhkan sikap intoleransi di kalangan siswa yang bertentangan dengan tujuan pendidikan agama itu sendiri. ${ }^{40}$ Pada tatar pembinaan agama, kota Kendari dapat dikatakan masih aman, namun demikian penelitian-penelitian lebih lanjut harus terus dilakukan mengingat Kota Kendari adalah pintu masuk bagi kehadiran paham-paham keagamaan, dan ini sudah mulai terlihat dari hadirnya lembagalemmbaga pendidikan Islam yang mengusung paham salafi bahkan Wahabi di kota ini.

\section{E. Pendidikan Toleransi Bagi Remaja Di Kota Kendari}

Agama sangatlah penting untuk pedoman hidup umat muslim, karena pendidikan agama bisa membuat muslim lebih bisa menjalankan perintah dan menjauhi larangan-Nya, yang memuat aturan-aturan kehidupan dan pengendali dari dari perbuatan keji dan mungkar. Pendidikan toleransi, dalam perspektif pendidikan Islam, mengarah pada konsep pluralitas, atau pendidikan pluralis atau pendidikan multikultural. Orientasi pendidikan toleransi mengarh pada proses penyadaran agama yang berwawasan pluralitas dan berwawasan multikultural. Arah pendidikan ini mengarahkan pada nilai toleransi. ${ }^{41}$

Pendidikan toleransi oleh para orang tua diberikan dalam bentuk pendidikan agama Islam secara tidak langsung mengarahkan pada kata-kata toleransi. Akan tetapi mengandung nilai-nilai toleransi. Pendidikan yang diberikan para orang tua bagi remaja di Kota Kendari yang pertama adalah pendidikan kepada remaja agar senantiasa menghargai orang yang lebih tua walaupun dia beragama lain. Hal ini sesuai dengan pernyataan informan bahwa; "Orang tua memberikan pendidikan pendidikan kepada remaja agar senantiasa menghargai orang yang lebih tua walaupun dia beragama lain"42

Pernyataan tersebut senada dengan pernyataan seorang informan bahwa;

\footnotetext{
${ }^{37}$ Zuhairi Misrawi, Al-quran Kitab Toleransi (Jakarta: Grasindo, 2010), h. 75

38 www.swatt-online.com/2011/04/lakip-pemerintah-harus-tinjaukembali-pendidikan-agama-islam / Diakses tanggal 12 Oktober 2017.

${ }^{39}$ Novan Ardy Wiyani, "Pendidikan Agama Islam Berbasis Anti Terorisme Di SMA", Jurnal Pendidikan Islam, Vol. I, No.2 (Desember 2012): 65-83.

40 Abdul Munip, "Menangkal Radikalisme Agama di Sekolah", Jurnal Pendidikan Islam, Vol. I, No. 2 (Desember 2012): 159-181.

${ }^{41}$ Ngainun Naim dan Achmad Sauqi, Pendidikan Multikultural: Konsep dan Aplikasi (Yogyakarta: ArRuzz Media, 2008).

${ }^{42}$ Ririn, Kepala Lurah,“Wawancara”, Benu-Benua, 4 Mei 2017
} 
Saya sebagai orang tua selalu membimbing anak saya supaya membiasakan menghormati dan menghargai orang lain maupun agama lain, kepada yang lebih tua dia selalu bersikap hormat kepada teman sebaya menghargainya dan kepada yang lebih muda harus menghargainya ${ }^{43}$

Kedua pernyataan tersebut didukung oleh pernyataan seorang informan bahwa:

Orang tua saya membimbing agar senantiasa menghargai orang yang lebih tua walaupun dia beragama lain ${ }^{44}$

Berdasarkan pernyataan tersebut di atas, dapat dipahami bahwa Pendidikan Islam bagi remaja di Kota Kendari, dengan memberikan pendidikan agar senantiasa menghargai orang yang lebih tua walaupun dia beragama lain telah terlaksana.

Pendidikan Islam bagi remaja di Kota Kendari, yang kedua adalah bimbingan remaja agar bersikap lemah lembut dalam kehidupan keluarga dan bermasyarakat. Hal ini sesuai dengan pernyataan informan bahwa; "Orang tua selalu memberikan bimbingan kepada anaknya bimbingan remaja agar bersikap lemah lembut dalam kehidupan keluarga dan bermasyarakat" ${ }^{\prime 4}$

Pernyataan tersebut senada dengan pernyataan seorang informan bahwa;

Dimulai dengan bersikap lemah lembut kepada anak kemudian memberikan pendidikan bersikap lemah lembut dalam kehidupan keluarga dan masyarakat dapat mempengaruhi sikap dan kepribadian disaat memasuki usia dewasa saya selaku orang tua dengan adanya perilaku tersebut remaja akan terbiasa memiliki kelembutan hati, tutur kata yang santun serta menjadi pribadi yang utuh ${ }^{46}$

Kedua pernyataan tersebut didukung oleh pernyataan seorang informan bahwa;

Dalam keluarga saya orang tua selalu memberikan contoh yang baik kepada anakanaknya tentang berperilaku yang baik yaitu bersikap lemah lembut kepada siapa saja. Dengan demikian saya selalu mengikuti nasihat, nasihat orang tua saya karena hal tersebut merupakan perilaku yang baik. ${ }^{47}$

Berdasarkan pernyataan tersebut di atas, dapat dipahami bahwa Pendidikan Islam bagi remaja di Kecamatan Kendari barat dengan memberikan bimbingan remaja agar bersikap lemah lembut dalam kehidupan keluarga dan bermasyarakat telah terlaksana.

Pendidikan Islam bagi remaja di Kota Kendari yang ketiga adalah memberikan bimbingan agar remaja membantu atau menolong sesama yang membutuhkan walaupun orang itu beragama lain. Hal ini sesuai dengan pernyataan informan bahwa:

Sikap tolong menolong atau saling membantu antar sesama dan pemeluk ajaran agama lain adalah salah satu agama Islam yang harus dilaksanakan sebagai ibadah sosial, tolong menolong dapat dilakukan bila pribadi-pribadi muslim memahami makna hidup bersama dengan kelompok masyarakat lain. kami di sini selaku orang tua selalu memberikan bimbingan kepada remaja agar menciptakan kondisi yang dapat mendorong agar senantiasa bersikap sosial dengan tolong menolong kepada siapa saja yang membutuhkan ${ }^{48}$

\footnotetext{
${ }^{43}$ Munawir, Orang Tua Remaja, “Wawancara”, Benu-Benua, 6 Mei 2017

${ }^{44}$ Sri Agusni, Remaja ,"Wawancara”, Benu-Benua, 7 Mei 2017

${ }^{45}$ Ririn, Lurah ,"Wawancara”,Benu-Benua, 4 Mei 2017

${ }^{46}$ Marnia, Orang Tua Remaja, “Wawancara”, Benu-Benua, 6 Mei 2017

${ }^{47}$ Lianti, Remaja "“Wawancara”, Benu-Benua 7 Mei 2017

${ }^{48}$ Ririn, Lurah,“Wawancara”, Benu-benua, 4 Mei 2017
} 
Pernyataan tersebut senada dengan pernyataan seorang informan bahwa:

Tidak semua orang tua dapat memberikan bimbingan dan sebagian besar orang tua di desa ini tidak memiliki pendidikan yang tinggi sehingga kurang mampu memberikan pendidikan Islam yang maksimal ${ }^{49}$

Kedua pernyataan tersebut didukung oleh pernyataan seorang informan bahwa:

Orang tua saya selalu memberikan bimbingan dan menjelaskan manfaat tolong menolong antar sesama manusia walaupun beragama lain olehnya itu saya terdorong untuk menanamkan sikap tolong menolong dalam kehidupan bermasyarakat ${ }^{50}$

Berdasarkan pernyataan tersebut di atas, dapat dipahami bahwa Pendidikan Islam bagi remaja di Kota Kendari, yakni dengan memberikan bimbingan agar remaja membantu atau menolong sesama yang membutuhkan walaupun orang itu beragama lain telah terlaksana.

Pendidikan Islam bagi remaja di Kota Kendari yang ke empat adalah membimbing remaja agar tidak mencela pemeluk agama lain. Hal ini sesuai dengan pernyataan informan bahwa:

Dengan kebiasaan-kebiasaan yang diberikan orang tua saya dalam keluarga dengan membimbing agar tidak mencela orang lain apalagi pemeluk agama lain sehingga kami terbiasa untuk melaksanakan hal tersebut kami mudah menghormati pemeluk agama lain. selain itu sering menjelaskan manfaat dari pada segala bentuk tindakan yang baik sesuai ajaran agama yang akan kehidupan yang bahagia baik di dunia maupun di akhirat $^{51}$

Pernyataan tersebut di atas, senada dengan pernyataan seorang informan bahwa:

Perilaku dalam berkehidupan masyarakat kami selalu teringat dengan nasihat dan pendidikan yang diberikan orang tua kami yaitu pentingnya perilaku yang baik dan pentingnya membina hubungan silahturahmi antar umat beragama dengan demikian maka akan terjadi kedamaian antar umat beragama"52

Kedua pernyataan tersebut di tas, didukung oleh pernyataan seorang informan bahwa: Berkat bimbingan orang tua kami, pergaulan kami dalam kehidupan remaja kami sehari-hari antar remaja Islam dan agama lain dapat terlihat hubungan yang akrab serta terjalin silahturahmi yang baik hal tersebut sering lakukan apabila hari besar agama lain kami bersilahtirahmi di rumah mereka demikian pula sebaliknya hari besar Islam mereka datang bersilahturahmi kepada kami ${ }^{53}$

Berdasarkan pernyataan tersebut di atas, maka dapat dipahami bahwa Pendidikan Islam bagi remaja di Kota Kendari, yakni dengan membimbing dan pemahaman kepada remaja agar memiliki akhlak yang baik dalam bergaul, saling menghargai, menghormati serta tidak mencela pemeluk agama lain.

Pendidikan Islam bagi remaja di Kota Kendari yang ke lima adalah memberikan pendidikan bagi remaja agar senantiasa membina hubungan silaturahmi dengan pemeluk agama lain. Hal ini sesuai dengan pernyataan informan bahwa:

\footnotetext{
${ }^{49}$ Nonarni, Orang Tua Remaja, “Wawancara”, Benu-Benua, 6 Mei 2017

${ }^{50}$ Rahma Wati, Remaja ,"Wawancara”, Benu-Benua 7 Mei 2017

${ }^{51}$ Ririn, , Lurah ,"Wawancara”, Benu-Benua, 4 Mei 2017

${ }^{52}$ Muh. Ridwan, Orang Tua Remaja, “Wawancara”, Benu-Benua, 6 Mei 2017

${ }^{53}$ Husni Agusman, Remaja ,"Wawancara”, Mandonga, 7 Mei 2017
} 
Tidak semua orang tua memberikan pendidikan bagi remaja agar senantiasa membina hubungan silaturahmi dengan pemeluk agama lain, sebab mereka berfikir bahwa tidak patut membina hubungan silaturahmi dengan pemeluk agama lain ${ }^{54}$

Pernyataan tersebut di atas, senada dengan pernyataan seorang informan yang menyatakan bahwa:

Saya memberikan pendidikan bagi remaja agar senantiasa membina hubungan silaturahmi dengan pemeluk agama lain ${ }^{55}$

Pernyataan tersebut di atas, senada dengan pernyataan seorang informan yang menyatakan bahwa:

Perilaku dalam berkehidupan masyarakat kami selalu teringat dengan nasihat dan pendidikan yang diberikan orang tua kami yaitu pentingnya perilaku yang baik dan pentingnya membina hubungan silahturahmih antar umat beragama dengan demikian maka akan terjadi kedamaian antar umat beragama ${ }^{56}$

Kedua pernyataan tersebut didukung oleh pernyataan seorang informan bahwa:

Berkat bimbingan orang tua kami, pergaulan kami dalam kehidupan remaja kami sehari-hari antar remaja Islam dan agama lain dapat terlihat hubungan yang akrab serta terjalin silahturahmi yang baik hal tersebut sering lakukan apabila hari besar agama lain kami bersilahtirahmi di rumah mereka demikian pula sebaliknya hari besar Islam mereka datang bersilahturahmi kepada kami ${ }^{57}$

Kedua pernyataan tersebut didukung oleh pernyataan seorang informan bahwa: Orang tua memberikan pendidikan bagi remaja agar senantiasa membina hubungan silaturahmi dengan pemeluk agama lain ${ }^{58}$

Mengacu pada pernyataan informana di atas, maka dapat dipahami bahwa Pendidikan Islam bagi remaja di Kota Kendari, yakni dengan memberikan pendidikan bagi remaja agar senantiasa membina hubungan silaturahmi dengan pemeluk agama lain telah terlaksana.

Hal ini sesuai dengan pernyataan informan bahwa:

Tidak semua orang tua memberikan pendidikan bagi remaja agar senantiasa membina hubungan silaturahmi dengan pemeluk agama lain, sebab mereka berfikir bahwa tidak patut membina hubungan silaturahmi dengan pemeluk agama lain ${ }^{59}$

Pernyataan tersebut di atas, senada dengan pernyataan seorang informan yang menyatakan bahwa:

Saya memberikan pendidikan bagi remaja agar senantiasa membina hubungan silaturahmi dengan pemeluk agama lain ${ }^{60}$

Pernyataan tersebut di atas, senada dengan pernyataan seorang informan yang menyatakan bahwa:

Perilaku dalam berkehidupan masyarakat kami selalu teringat dengan nasihat dan pendidikan yang diberikan orang tua kami yaitu pentingnya perilaku yang baik dan

\footnotetext{
${ }^{54}$ Rahmat, Lurah"Wawancara Mandonga, 4 Mei 2017

${ }^{55}$ Rusmanto, Orang Tua Remaja, “Wawancara”, Mandonga 6 Mei 2017

${ }^{56}$ Muh. Ridwan, Orang Tua Remaja, “Wawancara”, Benu-Benua, 6 Mei 2017

${ }^{57}$ Rusmin, Remaja ,“Wawancara”, Mandonga, 7 Mei 2017

${ }^{58}$ Masniatin, Remaja ,“Wawancara”,Mandonga 7 Mei 2017

${ }^{59}$ Ririn, , Lurah ,"Wawancara”, Benu-Benua, 4 Mei 2017

${ }^{60}$ Rusmanto, Orang Tua Remaja, “Wawancara”, Mandonga 6 Mei 2017
} 
pentingnya membina hubungan silahturahmih antar umat beragama dengan demikian maka akan terjadi kedamaian antar umat beragama ${ }^{61}$

Kedua pernyataan tersebut didukung oleh pernyataan seorang informan bahwa:

Berkat bimbingan orang tua kami, pergaulan kami dalam kehidupan remaja kami sehari-hari antar remaja Islam dan agama lain dapat terlihat hubungan yang akrab serta terjalin silahturahmi yang baik hal tersebut sering lakukan apabila hari besar agama lain kami bersilahtirahmi di rumah mereka demikian pula sebaliknya hari besar Islam mereka datang bersilahturahmi kepada kami ${ }^{62}$

Berdasarkan pernyataan tersebut di atas, dapat dipahami bahwa Pendidikan Islam bagi remaja di Kota Kendari. Dengan memberikan pendidikan bagi remaja agar senantiasa membina hubungan silaturahmi dengan pemeluk agama lain telah terlaksana.

Pendidikan agam Islam yang diberikan pada remaja di kota Kendari haruslah dapat membentuk sikap-sikap menghargai perbedaan, sebagaimana dijelaskan Walzer bahwa toleransi harus mampu membentuk kemungkinan-kemungkinan sikap, antara lain: bersedia menerima perbedaan, mengubah penyeragaman menjadi keragaman, mengakui hak orang lain, dan menghargai eksistensi orang lain. ${ }^{63}$ Penelitian ini sejalan dengan apa yang ditemukan Zainul Akhyar, Harpani Matnuh, Siti Patimah dalam penelitianya Di Desa Kolam Kanan dimana masyarakat di wilayah ini telah menerapkan sikap mengakui hak orang lain untuk memeluk agama sesuai dengan kepercayaanya masing-masing dan mengakui hak pemeluk agama tersebut untuk melaksanakan ibadah sesuai dengan kepercayaannya ${ }^{64}$. Hasil penelitian ini masih perlu terus diuji untuk mengkaji implemetasi di lapangan, apakah hasil pembinaan agama dan pembinaan nilai-nilai toleransi pada remaja di Kota Kendari masih berjalan secara baik dan efektif, jika remaja di kota tersebut mendapatkan pengaruh pahampaham radikal secara terus menerus. Oleh sebab itu, perlu dilakukan penelitian-penelitian lain untuk membuktikan asumsi ini.

\section{F. Penutup}

Masyarakat Kota Kendari sangat memperhatikan terhadap pembinaan sikap toleransi antara umat beragama bagi remaja di Kota Kendari. Menurut mereka, pembinaan sikap toleransi antara umat beragama adalah hal yang sangat penting untuk dimiliki oleh remaja di Kota Kendari, sebab dengan adanya pembinaan sikap toleransi antara umat beragama tersebut maka remaja tidak akan saling mempersoalkan perbedaan keyakinan kepada pemeluk agama lain, mengganggu pemeluk lain ketika menjalankan ibadah keagamaan, tidak memaksa pemeluk agama lain untuk masuk Islam serta tidak memaksa pemeluk agama lain untuk mengikuti kegiatan-kegiatan keagamaan.

Pelaksanaan pola pendidikan Islam bagi remaja di Kota Kendari adalah memberikan pendidikan kepada remaja agar senantiasa menghargai orang yang lebih tua walaupun dia beragama lain, memberikan pendidikan agar remaja bersikap lemah lembut dalam kehidupan keluarga dan bermasyarakat, memberikan pendidikan agar remaja membantu atau menolong sesama yang membutuhkan walaupun orang itu beragama lain, orang tua membimbing remaja

\footnotetext{
${ }^{61}$ Muh. Ridwan, Orang Tua Remaja, “Wawancara”, Benu-Benua, 6 Mei 2017

${ }^{62}$ Rusmin, Remaja ,“Wawancara”, Mandonga, 7 Mei 2017

${ }^{63}$ Lihat Zuhairi Misrawi, "Pengertian Masalah Toleransi". Medical Science and Mysticism (Online), Diakses 05 Mei 2017.

${ }^{64}$ Zainul Akhyar, Harpani Matnuh, Siti Patimah, "Implementasi Toleransi Antar Umat Beragama Di Desa Kolam Kanan Kecamatan Barambai Kabupaten Barito Kuala”, Jurnal Pendidikan Kewarganegaraan, Vol. 5, No. 9, (Mei 2015): 724-734
} 
agar tidak mencela pemeluk agama lain serta memberikan pendidikan bagi remaja agar senantiasa membina hubungan silaturahmi dengan pemeluk agama lain.

\section{Daftar Pustaka}

Abdullah, Masykuri. Pluralisme Agama dan Kerukunan dalam Keragaman. Jakarta: Penerbit Buku Kompas, 2001.

Ahnaf, Mohammad Iqbal. 2012. Contesting Morality: Youth Piety and Pluralism in Indonesia, $\begin{array}{lllllll}\text { Pluralism } & \text { Working } & \text { Paper } & 2012 & / & \text { NO } & 10 .\end{array}$ https://www.uvh.nl/uvh.nl/up/ZwtndrvIwB PWP no 10 Contesting_Morality.pdf.

Diakses 17 Mei 2017.

Akhyar, Zainul, Harpani Matnuh, Siti Patimah. "Implementasi Toleransi Antar Umat Beragama Di Desa Kolam Kanan Kecamatan Barambai Kabupaten Barito Kuala”, Jurnal Pendidikan Kewarganegaraan, Vol. 5, No. 9, (Mei 2015): 724-734.

Ali, H. M dkk. Islam untuk Disiplin Ilmu Hukum Sosial dan Politik. Jakarta: Bulan Bintang, 1989).

Arifin, H.M. Ilmu Pendidikan Islam. Jakarta: PT. Bumi Aksara, 2014.

Daradja, Zakiah. Ilmu Pendidikan Islam. Jakarta: Bumi Aksara, 1992. . Ilmu Pendidikan Islam. Jakarta: Bumi Aksara, 2008.

Departemen Agama RI, Hubungan Antar Umat Beragama (Tafsir Al-quran Tematik). Jakarta: Departemen Agama, 2008.

Effendi, Djohan. Dialog antar Agama, bisakah melahirkan kerukunan? Agama dan Tantangan Zaman. Jakarta: LP3ES, 1985.

Farikhatin, Anis. "Membangun Keberagamaan Inklusif-Dialogis di SMA PIRI I Yogyakarta". Jurnal Ma'arif. Vol. 8 No. 1 (Juli 2013): 109-131.

Gaus AF, Ahmad. "Pemetaan Problem Radikalisme di SMU Negeri di 4 Daerah". Jurnal Ma'arif, Vol. 8 No. 1 (Juli 2013): 174-191.Imadadun, Rahmat. Islam Pribumi Mendialogkan Agama, Membaca Realita. Jakarta: Erlangga, 2003.

Hasil Survey PPIM UIN Syarid Hidayatullah Jakarta 2018, "Pelita yang Meredup: Potret Keberagamaan Guru Indonesia”. Jakarta: Pusat Pengkajian Islam dan Masyarakat (PPIM) UIN Syarif Hidayatullah, 2018.

Listyarti, Retno. "Pendidikan Multikultural dan Anti Kekerasan Melalui Permainan Garis". Jurnal Ma'arif, Vol. 8 No. 1 (Juli 2013): 97-108.

Maksum, Ali "Model Pendidikan Toleransi Di Pesantren Modern Dan Salaf", Jurnal Pendidikan Agama Islam Vol. 03, No. 01, (Mei 2015): 82-108.

Misrawi, Zuhairi. Al-quran Kitab Toleransi. Jakarta: Grasindo, 2010. 
.- "Pengertian Masalah Toleransi. Medical Science and Mysticism (Online), Diakses 05 Mei 2017.

Mubarak, M. Zaki. "Dari Semangat Islam Menuju Sikap Radikal: Pemikiran dan Perilaku Keberagamaan Mahasiswa UIN Syarif Hidayatullah Jakarta". Jurnal Ma'arif, Vol. 8 No. 1 (Juli 2013): 192-217.

Munip, Abdul. "Menangkal Radikalisme Agama di Sekolah”, Jurnal Pendidikan Islam, Vol. I, No. 2 (Desember 2012): 159-181.

Naim, Ngainun Naim dan Achmad Sauqi. Pendidikan Multikultural: Konsep dan Aplikasi. Yogyakarta: Ar-Ruzz Media, 2008.

Nilan, Pam dan Feixa, Charles. Global Youth? Hybrid Identity, Plural Worlds. New York: Routledge, 2006.

Rahman, Abdul Saleh. Pendidikan Agama dan Pembangunan Watak Bangsa. Jakarta: PT. Raja Grafindo Persada, 2006.

Rosyadi, Khoiron. Pendidikan Profetik. Jogyakarta: Pustaka Pelajar, 2004.

Santoso, Ananda. Kamus Praktis Bahasa Indonesia Untuk Pelajar dan Umum. Surabaya: Dara Publika, 1997.

Sarapung, Elga. Pluralisme, Konflik dan Perdamaian. Yogyakarta: Pustaka Pelajar, 2002.

Sulaiman, Dadang. Psikolog Remaja Dimensi-Dimensi Remaja Perkembangan. Bandung: CV. Mandar Maju, 1995.

Syahid, Ahmad. Riuh di Beranda Satu:Peta Kerukunan Umat Beragama di Indonesia. Jakarta: Departemen Agama RI bekerjasama dengan Badan Litbang Agama dan Diklat Keagamaan serta Puslitbang Kehidupan Beragama, 2003.

Syamsul Nizar, Al-rasyidin. Filsafat Pendidikan Islam. Jakarta: Grafindo Persada, 2005.

Tafsir, Ahmad. Ilmu Pendidikan Dalam Prespektif Islam. Bandung: Remaja Rosdakarya, 2001.

Wiyani, Novan Ardy. "Pendidikan Agama Islam Berbasis Anti Terorisme Di SMA". Jurnal Pendidikan Islam. Vol. I, No.2 (Desember 2012): 65-83.

Zainal, Asliah. "Pola Pendidikan Dan Pola Dakwah Islamic Centre Mu'adz Bin Jabal (ICM) Di Kota Kendari”, Jurnal Al Izzah, Vol. Vol 12, No.2, Nov 2017: 44-66. http://ejournal.iainkendari.ac.id/al-izzah/article/view/640/594. Diakses tanggal 5 Februari 2018.

\section{Surat Kabar;}

Harian Umum Kompas Nasional. 02 maret 2016. Survei Maarif Institute: Benih Radikalisme di Kalangan Remaja Mengkhawatirkan. 
Majalah Tempo, "Investigas Paham Radikal di kampus Kita”, 28 Mei-3 Juni 2018.

\section{Website;}

www.swatt-online.com/2011/04/lakip-pemerintah-harus-tinjaukembali-pendidikan-agamaislam / Diakses tanggal 12 Oktober 2017. 